\author{
소형 사각 곤포기를 이용한 옥수수 사각 압축곤포 사일리지 \\ 조제에 관한 연구 \\ 최기춘 ${ }^{1} \cdot$ 조남철 $^{1} \cdot$ 정민웅 $^{1} \cdot$ 김종근 $^{1} \cdot$ 신재순 $^{1} \cdot$ 이경동 $^{2} \cdot$ 임영철 $^{1} \cdot$ 김원호 $^{1} \cdot$ 오영균 $^{1} \cdot$ \\ 김천만 $^{1} \cdot$ 김혁기 $^{1} \cdot$ 한동배 $^{1}$
}

\title{
Study on Manufacture of Square Baled Corn Silage Using Square Silage Wrapping Compressor
}

\author{
Ki Choon Choi ${ }^{1}$, Nam Chul Cho', Min-Woong Jung', Jong Geun Kim¹, Jae Soon Shin', \\ Kyung Dong Lee ${ }^{2}$, Young Chul Lim¹, Won Ho Kim¹, Young Keun $\mathrm{Oh}^{1}$, Cheon Man Kim', \\ Hyuk Gi Kim ${ }^{1}$ and Dong Bae Han $^{1}$
}

\begin{abstract}
This study was conducted to investigate the effect of harvest stage of corn on the quality of square baled corn silage manufactured with corn grown in paddy land of Department of Animal Resources Development, National Institute of Animal Science, RDA from 2009 to 2010. Corn "Kwangpyungok" was harvested at three different growth stages (milk, yellow ripen and ripen stage) and ensiled at each harvest time. Square baled corn silage was manufactured by use of square silage wrapping compressor. Each treatment was replicated three times. The content of crude protein $(\mathrm{CP})$ of corn in square baled corn silage decreased with delayed maturity, but the content of ADF (acid detergent fiber), NDF (neutral detergent fiber), TDN (total digestible nutrient) and in vitro dry matter digestibility (IVDMD) were not changed. The content of moisture, $\mathrm{pH}$ and the nutritive values at three different harvest stages were not influenced by the method of silage manufacture and inoculant. The content of lactate of square baled corn silage harvested in milk stage of corn was significantly increased, as compared with that of round baled corn silage $(\mathrm{P}<0.05)$, but in stage of yellow ripen was significantly decreased $(\mathrm{P}<0.05)$. The content of acetate in square baled corn silage significantly decreased with delayed harvest maturity, as compared with that of round baled corn silage $(\mathrm{P}<0.05)$. Flieg's score of square baled corn silage harvested in milk stage of corn was slightly higher than that of round baled corn silage, but Flieg's scores in yellow ripen stage and ripen stage were not influenced by the method of silage manufacture. Flieg's score with delayed maturity was not influenced by the method of silage manufacture and inoculant. The manufacture of square baled corn silage was proved to be suitable for the fermentation of corn silage. Therefore, this study suggest that square baled corn silage can be a way of new silage manufacture technique.
\end{abstract}

(Key words: Corn, Silage, Square bale, Round bale, Quality, Organic acid)

\footnotetext{
${ }^{1}$ 농촌진흥청 국립축산과학원 (National Institute of Animal Science, RDA, Cheonan 331-808, Korea)

${ }^{2}$ 동신대학교 (Dongsin University, Naju, 520-714, Korea)

Corresponding author: Ki Choon Choi, National Institute of Animal Science, RDA, Cheonan 331-808, Korea.
} Tel: +82-41-580-6755, Fax: +82-41-580-6779, E-mail: choiwh@korea.kr 


\section{I. 서 론}

최근 쌀 수요 감소에 따른 벼 대체 사료작물 재배 필요성이 강조되고 있는 상황에서 논을 이용한 양질 조사료 생산기반 구축은 탄력을 받을 것으로 보인다. 특히, 논을 활용한 여름 사료작물인 옥수수나 수수류를 이용한 곤포 사 일리지 조제기술개발은 논의 활용측면 뿐만 아 니라 유통사료 활성화 측면에서 대단히 중요하 다. 이제까지 청보리, 호밀, 이탈리안 라이그라 스 등 동계 사료작물은 현재 보급이 일반화 되 어있는 원형곤포기로 곤포조제 (김 등, 2010; 김 등, $2006 \mathrm{a}$; 김 등, $2006 \mathrm{~b}$; 김 등, 2004 ; 김 등, 2001 ; 김 등, $2000 \mathrm{a}$; 김 등, $2000 \mathrm{~b}$; 김 등, 2000c; 김 등, 1995 ; Bevre, 1988; Romahn, 1988)가 가능하나, 줄기가 굵고 단단한 옥수수 나 수수류는 곤포기로 조제가 어려움이 있는 것으로 보고되고 있다. 특히, 일반농가에서는 기존의 곤포기에 절단장치 $(4 \sim 5$ 개 $\rightarrow 7 \sim 8$ 개 $)$ 을 추가해 곤포를 조제하고 있으나 절단 길이가 길고 불균일하게 혼합되어 발효품질이 떨어지 고 장기저장을 하기 어려운 것으로 알려져 있 다. 이러한 이유로 양축농가는 새로운 곤포사 일리지 제조기술에 대한 필요성이 대두되기 시 작하였다.

현재 주로 사용되고 있는 원형곤포는 곤포무 게는 $500 ~ 1,000 \mathrm{~kg}$ 으로 소규모 축산농가에서는 취급과 급여가 불편하기 때문에 유통이 편리하 고 취급이 용이한 소포장 압축사일리지 (20 30 $\mathrm{kg}$ 내외)의 조제기술 개발에 대한 요구도가 높 아짐에 따라 신 등 (2010)은 사각 압축곤포(소 포장) 사일리지 조제장치 (Square silage wrapping compressor)를 개발하였다. 이 사각 압축곤포 사일리지 조제장치의 개발은 중소규모 축산농 가는 물론 대규모 농가에서도 트랙터 동력이나 일반 전기 등의 이용이 가능하여 양질의 옥수 수 사일리지를 비롯하여 수수류, 청보리, 호밀, 이탈리안 라이그라스 등 모든 사료작물을 유통 이 가능한 소포장 압축조사료로 조제가 가능하
기 때문에 축산농가에서 양질의 조사료를 연중 안정적으로 이용할 수 있어 조사료 자급률을 향상뿐만 아니라 사료비 절감 효과가 있을 것 으로 보고한 바 있다(신 등, 2009).

따라서 본 연구에서는 신 등 (2009)이 개발한 사각 압축곤포(소포장) 사일리지 제조 장치를 이용하여 옥수수의 수확시기에 따라 사각 압축 곤포 사일리지를 조제하였을 때 옥수수의 사일리 지 사료가치 및 유기산 등 품질 변화를 조사하여 품질이 우수한 옥수수의 소포장 사일리지 제조를 위한 기초자료를 얻기 위해서 수행하였다.

\section{ㅍ. 재료 및 방법}

\section{1. 포장시험 및 사일리지 제조}

본 시험은 2009년부터 2010년까지 충남 천안 논에서 2년간 수행되었다. 공시초종으로 옥수 수(광평옥)를 4월 중순에 파종하였는데 옥수수 의 파종은 트랙터에 부착된 옥수수 파종기로 파종하였고, 시비는 옥수수 표준시용량으로 200$150-150 \mathrm{~kg} / \mathrm{ha}\left(\mathrm{N}-\mathrm{P}_{2} \mathrm{O}_{5}-\mathrm{K}_{2} \mathrm{O}\right)$ 를 시비하였다. 이중 질소는 기비로 $50 \%$, 추비로 $50 \%$ 시용하였으며 인산과 칼리는 전량기비로 시용하였다.

수확은 옥수수는 유숙기 (8월 초순), 황숙기 (8월 중순), 완숙기 (8월말), 즉 황숙기 기준으 로 유숙기는 10 일 전, 완숙기는 10 일 후에 수 확하였다. 수확시기별 수분 함량은 각각 77 $79 \%, 73 \sim 75 \%$ 및 57 63\%을 보였다.

옥수수는 수확시기별로 옥수수 수확기 (Kemper $\mathrm{C} 3000 \mathrm{H}$, 독일)로 수확 (절단길이 $2 \sim 3 \mathrm{~cm}$ )하여 사일리지를 조제하였으며 이때 옥수수 젖산균 첨가제 (청미바이오, 한국)를 처리하여 각 처리 당 3 반복의 사각 압축곤포 및 원형 베일 사일 리지를 조제하였다.

옥수수 사각 압축곤포 사일리지는 매 수확시 기마다 옥수수 생초 $25 \mathrm{~kg}$ 을 Fig. 1 (신 등, 2009)에서 보는 바와 같이 사각 압축성형 챔버 에 넣고 유압을 이용하여 소형의 직사각형으로 

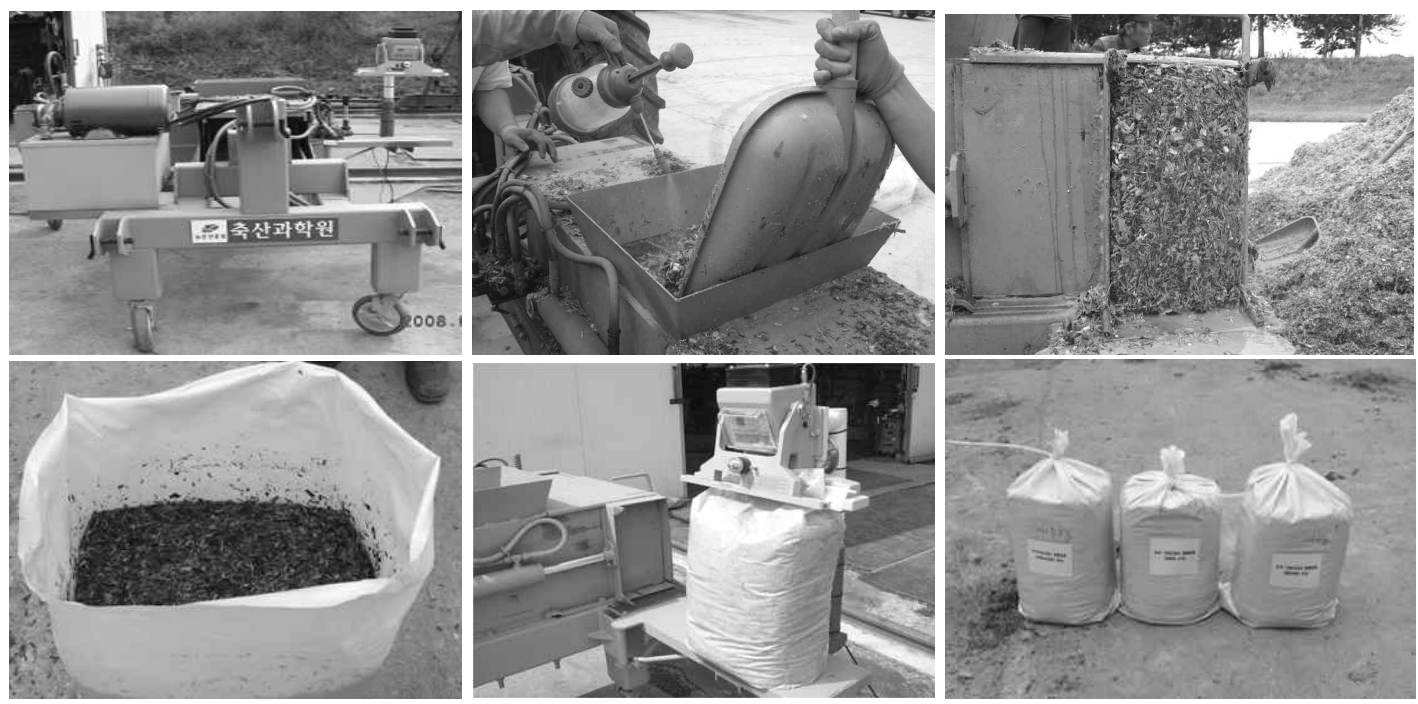

Fig. 1. Making of corn silage using square silage wrapping compressor.

압축하고, 배출대기 챔버의 배출구에 포장지를 걸어 놓은 상태에서 압축된 사일리지를 다시 유압을 이용하여 포장지 안으로 밀어낸 다음, 압축 사일리지가 들어있는 포장지 상단부의 공 기를 제거하고 난 다음 실링기로 완전 밀봉한 다음(신 등, 2009), 그늘에서 보관한 후 원형 베일 사일리지와 함께 약 60 일을 보관한 후 개 봉하여 사료가치와 품질 등을 조사하였다. 그리 고 젖산균은 분무기로 권장량을 골고루 살포하 여 조제하였다. 사각 베일제조에 사용된 비닐은 시중에서 비료나 농후사료 등 보관용으로 시판 되고 있는 것을 비닐포대 그대로 사용하였다.

대조구의 원형곤포 사일리지 조제는 옥수수 전용 원형곤포기 (Bio325, $\mathrm{ViCon}$, 독일)를 이용 하여 지름 $120 \mathrm{~cm}$, 높이 $120 \mathrm{~cm}$ 규격의 대형 원형곤포를 만들었고 곤포화와 동시에 분무기 로 젖산균 첨가제를 권장량 골고루 살포한 다 음 Wrapper(Bio325, ViCon, 독일)를 이용하여 16 18겹의 비닐을 감아 제조하였다. 사일리지 wrapping에 쓰인 비닐은 두께가 $25 \mu \mathrm{m}$ 이고 폭 은 $800 \mathrm{~mm}$ 이며 길이는 $1,800 \mathrm{~m}$ 인 백색 비닐을 사용하였다

2. 사료가치 분석
옥수수 사일리지의 사료가치를 조사하기 위 하여 각 시험구에서 저장 60 일 후 사일리지 시 료채취기 (Uni-Forage Sampler; STAR QUALITY SAMPLER Co. Canada)로 각 처리구당 약 500 $\mathrm{g}$ 을 취하여 일부는 $65^{\circ} \mathrm{C}$ 순환식 송풍건조기에 서 3일간 건조 후 분쇄하여 시료의 Crude protein (CP)은 A.O.A.C.법 (1990)에 의해 분석하 였고, Neutral detergent fiber(NDF) 및 Acid detergent fiber (ADF) 함량은 Goering 및 Van soest법 (1970)으로 분석하였다. In vitro 건물소 화율은 Tilley 및 Terry법(1963)을 Moore (1970) 가 수정한 방법을 이용하였으며, TDN 함량은 Jurgens (1982) 방법을 수정하여 계산하였다. 그 리고 나머지 일부는 $-20^{\circ} \mathrm{C}$ 냉동고에 보관하였 다가 사일리지 특성 조사에 사용하였다.

사일리지의 $\mathrm{pH}$ 와 유기산 성분은 개봉한 사 일리지 $10 \mathrm{~g}$ 을 증류수 $100 \mathrm{ml}$ 에 넣고 냉장고에 서 주기적으로 흔들어 주면서 24시간 보관 후 4중 거즈(Gauze)로 1차 거른 후 여과지 (Whatman No. 6)를 통하여 걸러서 추출액을 조제하여 $\mathrm{pH}$ 는 $\mathrm{pH}$ meter (HI 9024; HANNA Instrument Inc. UK)로, 그리고 젖산은 $0.22 \mu \mathrm{m}$ 실린지 필터를 사용하여 여과시킨 다음 HPLC (HP1100. Agilent Co. USA)로 분석하였다. 초산 
과 낙산 분석은 chromatography (GC-450, Varian Co., USA)를 이용하여 분석하였다. 추출액은 분석에 이용할 때까지 $-70^{\circ} \mathrm{C}$ 에서 냉동보관 하 였다.

본 시험에서 얻은 모든 결과는 Windows 용 SPSS/PC (Statistical Package for the Science, ver 12.0. USA) 통계프로그램을 이용하여 분석하였 다. 처리간의 평균비교는 t-test를 시행하였고 최소유의성을 검정은 P-value가 0.05로 평가하 였다.

\section{III. 결과 및 고찰}

1. 옥수수 사각 압축곤포 사일리지의 수분 함량 및 $\mathrm{pH}$

숙기별 옥수수 사각 압축곤포(소포장) 사일 리지에 대한 수분 함량은 Fig. 2에서 보는 바와 같다. 옥수수 사각 압축곤포 사일리지 수분함 량은 수확시기가 늦어짐에 따라 현저하게 감소 하였다 $(\mathrm{P}<0.05)$. 그리고 젖산균의 첨가 유무에 관계없이 수분 함량은 거의 영향을 받지 않았 다. 또한 대조구인 원형곤포 사일리지의 수분 함량도 사각 압축곤포 사일리지와 비슷한 경향 을 보였다.

숙기별 옥수수 사각 압축곤포 사일리지의

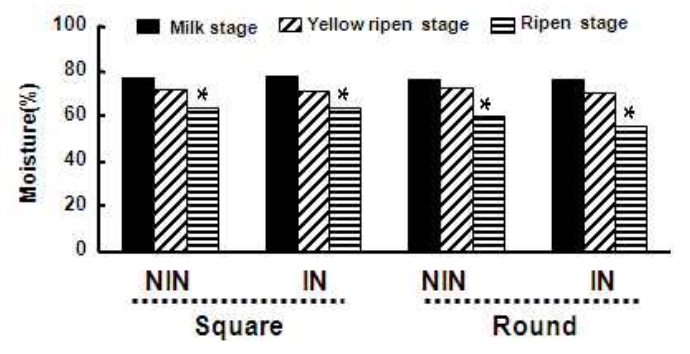

Fig. 2. Moisture content of square baled corn silage according to harvest time of corn and inoculant treatment.

NIN: Non-inoculation of inoculant, IN: Inoculation of inoculant, Square: Square bale, Round: Round bale.

* vs Milk stage $(\mathrm{P}<0.05)$.
$\mathrm{pH}$ 는 3.51 3.75로써 안정된 상태를 보였으며 또한 원형곤포 사일리지 $\mathrm{pH}$ 도 3.64 3.74로써 안정된 값을 보였다 (Table 2). 그리고 옥수수 사각 압축곤포 및 원형곤포 사일리지는 젖산균 의 첨가유무에 상관없이 $\mathrm{pH}$ 는 안정된 상태를 유지하였다.

일반적으로 사일리지의 품질과 사료가치는 사일리지 제조시기에 따라 영향을 받는데, 즉 우리나라의 경우 사료작물의 수확적기에 예취 하여 사일리지를 제조하는 것이 아니라 일손과 기후여건에 따라 사일리지를 제조하는 경우가 대부분이기 때문에 수확적기보다 일찍 또는 늦 게 예취하여 사일리지를 조제하기 때문에 사일 리지의 수분 함량 차이가 심한 실정이다. 목초 나 사료작물의 사일리지 제조시 수분 함량을 조절하기 위해서 예건을 실시하여 사일리지의 품질과 $\mathrm{pH}$ 의 연관성을 조사한 연구가 많이 수 행되어졌으며 (임 등, 2009; 송 등, 2009; 김 등, $2006 \mathrm{~b}$; Manyawa 등, 2003; 김 등 1996), 김 등 (2010)은 사일리지의 $\mathrm{pH}$ 변화는 사료작물의 초 종과 사일리지 제조시 건물함량에 따라 $\mathrm{pH}$ 의 증감이 달라질 수 있다고 하였는데, 본 연구에 서는 숙기가 다르고 수분 함량이 차이가 심하 게 나타났음에도 불구하고 $\mathrm{pH}$ 의 변화는 거의 관찰 되지 않았다. 이러한 결과는 모든 사일리 지에서 밀봉이 잘 되고 수분과 당이 충분하여 완전한 발효가 일어났거나 2 차 발효가 없었다 는 것을 의미한다. 그러나 일반적으로는 재료 의 수분 함량에 따라서 $\mathrm{pH}$ 차이의 변화가 예 상되기 때문에 옥수수 사각 압축곤포 사일리지 나 원형곤포 사일리지 제조시 수분함량을 고려 하여 수확시기를 결정해야 바람직할 것으로 생 각된다. 특히, 수분이 과다할 경우 사일리지의 품질과 사료가치의 질을 저하시키는 요일이 될 뿐 아니라 가축의 기호성을 감소시켜 섭취량을 떨어뜨리는 요인(김 등, 2009)이 되므로 최근 정부에서는 사일리지 품질에 따라 차등을 두어 보조금을 지급하고 있다 (농림수산부, 2010). 
2. 옥수수 사각 압축곤포 사일리지의 사료가치

숙기별 옥수수 사각 압축곤포 사일리지의 사 료가치는 Table 1에서 보는 바와 같다. 옥수수 사각 압축곤포 사일리지는 수확시기가 늦어짐 에 따라 조단백질 함량은 감소하는 경향을 보 였으며 $(\mathrm{P}<0.05)$ 섬유소인 $\mathrm{NDF}$ 와 $\mathrm{ADF}$ 함량은 비슷한 수준을 유지하였다. 그리고 젖산균 첨 가에 의해서 조단백질, $\mathrm{NDF}$ 와 $\mathrm{ADF}$ 함량 그리 고 TDN 함량도 영향을 받지 않았다.

옥수수 원형곤포 사일리지의 조단백질, $\mathrm{NDF}$ 와 $\mathrm{ADF}$ 함량도 숙기가 진행됨에 따라 옥수수 사각 압축곤포 사일리지와 비슷한 함량 변화를 보였고 TDN 함량도 사일지지 제조방법 및 젖 산균 첨가에 따라 큰 차이를 보이지 않았다.
일반적으로 대부분의 사일리지는 수확시기에 따라서 사료가치 변화가 발생하고 (김 등, 2010; 김 등, 2008; 김 등, 2001) 특히, 젖산균에 의해 서 사료가치가 영향을 받는다고 보고하고 있는 데, 김 등 (2000b), Keady 및 Murphy (1996)은 젖산균 첨가로 $\mathrm{ADF}$ 및 $\mathrm{NDF}$ 함량이 감소된다 고 하였으며 Kennedy 등 (1989)도 젖산균 첨가 로 $\mathrm{ADF}$ 함량이 감소된다고 하였다. 그러나 Gordon (1989) 및 Patterson 등 (1997)은 젖산균 처리로 $\mathrm{ADF}$ 함량이 증가한다고 보고하였으나 본 연구에서는 젖산균에 의해서 $\mathrm{NDF}$ 와 $\mathrm{ADF}$ 함량은 영향을 받지 않은 것으로 나타났다. 이 처럼 연구자의 따라 $\mathrm{ADF}$ 및 $\mathrm{NDF}$ 함량은 상반 된 보고를 하고 있기 때문에 지속적인 연구가 진행되어야 할 것으로 보인다.

Table 1. Effect of harvest of harvest time of corn and inoculant treatment on its nutritive values in square baled corn silage

\begin{tabular}{|c|c|c|c|c|c|c|c|c|c|c|c|c|c|c|c|c|c|}
\hline \multirow[b]{2}{*}{$\mathrm{SMM}^{1)}$} & \multirow[b]{2}{*}{$\begin{array}{l}\text { Inocu- } \\
\text { lant }\end{array}$} & \multirow[b]{2}{*}{ Year } & \multicolumn{5}{|c|}{ Milk stage } & \multicolumn{5}{|c|}{ Yellow ripen stage } & \multicolumn{5}{|c|}{ Ripen stage } \\
\hline & & & $\begin{array}{l}\mathrm{CP}^{6)} \\
(\%)\end{array}$ & $\begin{array}{c}\left.\mathrm{ADF}^{7}\right) \\
(\%)\end{array}$ & $\begin{array}{c}\mathrm{NDF}^{8)} \\
(\%)\end{array}$ & $\begin{array}{c}\left.\mathrm{TDN}^{9}\right) \\
(\%)\end{array}$ & $\begin{array}{c}\operatorname{IVDMD}^{10)} \\
(\%)\end{array}$ & $\begin{array}{l}\mathrm{CP} \\
(\%)\end{array}$ & $\begin{array}{l}\mathrm{ADF} \\
(\%)\end{array}$ & $\begin{array}{l}\mathrm{NDF} \\
(\%)\end{array}$ & $\begin{array}{l}\text { TDN } \\
(\%)\end{array}$ & $\begin{array}{c}\text { IVDMD } \\
(\%)\end{array}$ & $\mid \begin{array}{l}\text { CP } \\
(\%)\end{array}$ & $\begin{array}{c}\mathrm{ADF} \\
(\%)\end{array}$ & $\begin{array}{l}\text { NDF } \\
(\%)\end{array}$ & $\begin{array}{c}\text { TDN } \\
(\%)\end{array}$ & $\begin{array}{c}\text { IVDMD } \\
(\%)\end{array}$ \\
\hline \multirow{6}{*}{ Square ${ }^{2}$} & \multirow{3}{*}{$\mathrm{NTR}^{4)}$} & 2009 & 9.77 & 32.43 & 52.28 & 67.54 & 61.6 & .65 & 33.18 & 48.10 & 67.22 & 72.5 & 8.67 & 39.63 & 52.74 & 464.48 & 76.8 \\
\hline & & 2010 & 7.98 & 31.18 & 49.33 & 68.07 & 71.5 & 7.96 & 32.45 & 49.24 & 67.53 & 70.9 & 7.12 & 30.00 & 47.42 & 268.57 & - \\
\hline & & Mean & 8.87 & 31.80 & 50.81 & 67.80 & 66.6 & 8.30 & 32.82 & 48.67 & 67.37 & 71.7 & 7.89 & 34.82 & 50.08 & 86.52 & 76.8 \\
\hline & \multirow{3}{*}{$\mathrm{TR}^{5)}$} & 2009 & 10.25 & 30.50 & 51.27 & 68.36 & 63.1 & 8.85 & 32.79 & 47.69 & 67.38 & 72.7 & 8.48 & 39.68 & 54.29 & 964.46 & 76.2 \\
\hline & & 2010 & 7.10 & 34.37 & 53.82 & 66.71 & 61.6 & 8.16 & 29.75 & 48.29 & 68.68 & 73.1 & 8.07 & 30.96 & 46.13 & 368.16 & - \\
\hline & & Mean & 8.67 & 32.43 & 52.55 & 67.54 & 62.3 & 8.51 & 31.27 & 47.99 & 68.03 & 72.9 & 8.27 & 35.32 & 50.21 & 166.31 & 76.2 \\
\hline \multirow{6}{*}{ Round $^{3)}$} & \multirow{3}{*}{ NTR } & 2009 & 9.89 & 33.49 & 53.10 & 67.09 & 62.8 & 9.96 & 36.48 & 52.71 & 65.82 & 66.2 & 7.99 & 38.98 & 52.97 & 764.76 & 78.3 \\
\hline & & 2010 & 8.11 & 30.44 & 49.15 & 68.38 & 67.6 & 7.32 & 26.56 & 43.25 & 70.03 & 70.8 & 7.46 & 37.41 & 41.01 & 169.67 & - \\
\hline & & Mean & 9.00 & 31.96 & 51.12 & 67.74 & 65.2 & 8.64 & 31.52 & 47.98 & 67.92 & 68.5 & 7.72 & 38.20 & 46.91 & 167.21 & 78.3 \\
\hline & \multirow{3}{*}{ TR } & 2009 & 9.68 & 33.86 & 52.67 & 66.93 & 68.8 & 9.15 & 34.71 & 51.39 & 66.57 & 70.6 & 7.86 & 37.08 & 49.12 & 265.56 & 74.0 \\
\hline & & 2010 & 7.84 & 29.71 & 48.70 & 68.69 & 69.9 & 7.60 & 28.11 & 44.90 & 69.37 & 70.1 & 7.85 & 30.23 & 45.23 & 368.47 & - \\
\hline & & Mean & 8.76 & 31.79 & 50.69 & 67.81 & 69.3 & 8.38 & 31.41 & 48.15 & 67.97 & 70.3 & 7.85 & 33.65 & 47.17 & 767.02 & 74.0 \\
\hline \multicolumn{18}{|c|}{ Main-effect } \\
\hline \multicolumn{3}{|c|}{ Square } & 8.77 & 32.12 & 51.68 & 67.67 & 64.5 & 8.40 & 32.04 & 48.33 & 67.70 & 72.3 & $8.08 *$ & 35.07 & 50.14 & 466.42 & 76.5 \\
\hline \multicolumn{3}{|c|}{ Round } & 8.88 & 31.88 & 50.91 & 67.77 & 67.2 & 8.51 & 31.47 & 48.06 & 67.95 & 69.4 & $7.79 *$ & 35.92 & 47.04 & 467.12 & 76.1 \\
\hline \multicolumn{18}{|c|}{ Sub-effect } \\
\hline \multicolumn{3}{|c|}{ NTR } & 8.93 & 31.88 & 50.96 & 67.54 & 65.92 & 8.47 & 32.17 & 48.32 & 68.03 & 70.17 & $7.81 *$ & 34.01 & 48.53 & 366.31 & 77.6 \\
\hline \multicolumn{3}{|c|}{ TR } & 8.72 & 32.11 & 51.62 & 67.67 & 65.88 & 8.44 & 31.34 & 48.07 & 68.00 & 71.62 & $8.06^{*}$ & 34.48 & 48.69 & 966.67 & 75.1 \\
\hline
\end{tabular}

${ }^{1)}$ SMM: Silage making method, ${ }^{2)}$ Square: Square bale, ${ }^{3)}$ Round: Round bale, ${ }^{4)} \mathrm{NTR}$ : Non-treatment, ${ }^{5)}$ TR: Treatment, ${ }^{6)} \mathrm{CP}$ :Crude protein, ${ }^{7)} \mathrm{ADF}$ : Acid detergent fiber, ${ }^{8)} \mathrm{NDF}$ : Neutral detergent fiber, ${ }^{9)} \mathrm{TDN}$ : Total digestible nutrient, ${ }^{10)}$ IVDMD: in vitro dry matter digestibility.

* vs Milk stage $(\mathrm{P}<0.05)$ 
이상의 결과에서 보는 바와 같이 사일리지제 조 방법과 수확시기에 따라서 사료가치 변화가 관찰되었고 젖산균의 처리효과는 나타나지 않 았다. 이처럼 젖산균 처리효과가 나타나지 않 은 이유는 옥수수의 특성상 당분 함량이 충분 하였고 사일리지 제조시 밀봉 및 보관이 잘 관 리되어 유산균 첨가 없이도 발효가 양호하게 일어난 것으로 보여진다. 그러나 특히, 일반농 가 수준에서는 수확시기, 답압 및 밀봉이 불확 실한 경우가 대부분이기 때문에 사각 압축곤포 사일리지 제조시에 젖산균의 첨가는 사일리지 품질 유지에 매우 중요하기 때문에 젖산균의 첨 가는 반드시 수행되어져야 할 것으로 생각된다.

\section{3. 옥수수 사각 압축곤포 사일리지의 소화율}

옥수수 사각 압축곤포 사일리지의 in vitro 건물소화율은 숙기가 진행됨에 따라 증가되는 경향을 보였다. 옥수수 원형곤포 사일리지의 in vitro 건물소화율도 옥수수 사각 압축곤포 사일 리지의 in vitro 건물소화율과 비슷한 경향을 보였다. 젖산균의 첨가유무에 관계없이 사일리 지의 in vitro 건물소화율은 비슷한 수준을 보 였다 (Table 1).

사일리지의 in vitro 건물소화율은 숙기가 진 행됨에 따라 건물 소화율이 증가한다는 보고 (김 등, 2008)와 젖산균 첨가제가 건물 소화율 증가와 관련성이 있고 (Keady 및 Steen, 1994; Patterson 등, 1997) 그리고 반대로 소화율 개선 효과가 없는 것으로 보고(Smith 등, 1993; Steen 등, 1989) 등으로 대별되는데, 본 연구에 서는 사일리지 제조 방법과 수확시기에 따라 옥수수 사일리지의 in vitro 건물소화율이 개선 되는 효과를 보이지 않았다. 그러나 Hristov 및 McAllister (2002)는 사일리지에 미생물 첨가제 를 처리함으로써 in situ 건물 소화율에 영향을 주지는 않았다고 하였는데 본 연구에서도 유사 한 경향을 보여주었다. 그러나 Hristov 및 McAllister (2002)는 미생물 첨가제함으로써 젖
산균의 함량과 개봉 후 호기적 안정성을 개선 하는 데는 효과가 있었다고 보고하였는데, 일 반농가에서는 답압 및 밀봉이 좋지 않은 경우 가 많기 때문에 젖산균을 접종함으로써 사일리 지의 안정성에 관여하여 2차 발효 등을 최소화 하여 사료가치를 장시간 유지하는데 도움이 될 것으로 보여진다. in vitro 건물소화율은 초종과 제조시 건물함량에 따라 약간의 변화는 관찰될 수 있겠으나 옥수수 사일리지의 경우에는 수분 함량에 상관없이 높은 소화율을 유지하기 때문 에 사료가치가 우수하고 농가 작업이 용이한 시기에 예취하여 사각 압축곤포 사일리지를 조 제하는 것이 경제적이나 가급적 황숙기에 사각 압축곤포 사일리지를 조제 하는 것이 유리할 것으로 생각된다.

\section{4. 옥수수 사각 압축곤포 사일리지의 유기산 함량 변화 및 품질등급}

옥수수 수확시기별 옥수수 사각 압축곤포 사 일리지의 유기산 함량은 Table 2에서 보는 바 와 같다. 옥수수 사각 압축곤포 사일리지는 수 확시기가 늦어짐에 따라 젖산 함량은 현저하게 감소하였으며 초산 함량도 감소하였다 $(\mathrm{P}<0.05)$. 옥수수 원형곤포 사일리지는 수확시기가 늦어 짐에 따라 젖산 함량은 증가하였으나 초산 함 량은 현저하세 감소하였다 $(\mathrm{P}<0.05)$. 유숙기에서 옥수수 사각 압축곤포 사일리지의 젓산 함량은 원형곤포 사일리지보다 현저하게 증가하였으나 $(\mathrm{P}<0.05)$ 황숙기에서는 현저하게 감소하였다 $(\mathrm{P}<0.05)$. 숙기별 사각 압축곤포 사일리지의 초 산 함량은 원형곤포 사일리지보다 현저하게 감 소하였다 $(\mathrm{P}<0.05)$. 그리고 옥수수 사각 압축곤 포 및 원형곤포 사일리지의 낙산함량은 유숙 기 완숙기까지 거의 나타나지 않았다.

초산, 낙산 및 젖산 등의 비율을 이용하여 사일리지의 품질을 표시하는 Flieg's score는 Fig. 3에서는 보는 바와 같다. 옥수수 사각 압 축곤포 및 원형곤포 사일리지의 Flieg's score는 
Table 2. Effect of harvest of harvest time of corn and inoculant treatment on the acidity and the contents of lactic acid in square baled corn silage

\begin{tabular}{|c|c|c|c|c|c|c|c|c|c|c|c|c|c|c|}
\hline \multirow[b]{2}{*}{$\mathrm{SMM}^{1)}$} & \multirow{2}{*}{$\begin{array}{l}\text { Inocu- } \\
\text { lant }\end{array}$} & \multirow[b]{2}{*}{ Year } & \multicolumn{4}{|c|}{ Milk stage } & \multicolumn{4}{|c|}{ Yellow ripen stage } & \multicolumn{4}{|c|}{ Ripen stage } \\
\hline & & & $\mathrm{pH}$ & $\begin{array}{l}\text { Lactate } \\
\text { (\%DM) }\end{array}$ & $\begin{array}{l}\text { Acetate } \\
(\% \mathrm{DM})\end{array}$ & $\begin{array}{l}\text { Butyrate } \\
(\% \text { DM) }\end{array}$ & $\mathrm{pH}$ & $\begin{array}{l}\text { Lactate } \\
\text { (\%DM) }\end{array}$ & $\begin{array}{l}\text { Acetate } \\
\text { (\%DM) }\end{array}$ & $\begin{array}{c}\text { Butyrate } \\
\text { (\%DM) }\end{array}$ & $\mathrm{pH}$ & $\begin{array}{l}\text { Lactate } \\
\text { (\%DM) }\end{array}$ & $\begin{array}{l}\text { Acetate } \\
\text { (\%DM) }\end{array}$ & $\begin{array}{l}\text { Butyrate } \\
\text { (\%DM) }\end{array}$ \\
\hline \multirow{6}{*}{ Square $^{2)}$} & \multirow{3}{*}{$\mathrm{NTR}^{4)}$} & 2009 & 3.32 & 7.41 & 1.46 & 0.02 & 3.82 & 6.31 & 1.27 & 0.00 & 4.00 & 5.73 & 0.84 & 0.05 \\
\hline & & 2010 & 3.57 & 6.91 & 1.71 & 0.00 & 3.75 & 4.73 & 1.82 & 0.17 & 3.68 & 4.33 & 0.55 & 0.01 \\
\hline & & Mean & 3.45 & 7.16 & 1.58 & 0.01 & 3.79 & 5.52 & 1.55 & 0.09 & 3.84 & 5.03 & 0.69 & 0.03 \\
\hline & \multirow{3}{*}{$\mathrm{TR}^{5)}$} & 2009 & 3.38 & 7.91 & 1.59 & 0.00 & 3.75 & 5.57 & 1.07 & 0.00 & 3.66 & 4.94 & 0.76 & 0.03 \\
\hline & & 2010 & 3.77 & 3.56 & 3.01 & 0.09 & 3.68 & 5.15 & 1.38 & 0.00 & 3.66 & 4.20 & 0.56 & 0.01 \\
\hline & & Mean & 3.57 & 5.73 & 2.30 & 0.04 & 3.71 & 5.36 & 1.23 & 0.00 & 3.66 & 4.57 & 0.66 & 0.02 \\
\hline \multirow{6}{*}{ Round ${ }^{3)}$} & \multirow{3}{*}{ NTR } & 2009 & 3.76 & 2.25 & 6.78 & 0.00 & 3.75 & 6.69 & 4.46 & 0.00 & 3.75 & 4.88 & 1.07 & 0.05 \\
\hline & & 2010 & 3.76 & 4.87 & 5.13 & 0.00 & 3.62 & 6.95 & 2.19 & 0.00 & 3.59 & 5.62 & 0.85 & 0.00 \\
\hline & & Mean & 3.76 & 3.51 & 5.97 & 0.00 & 3.69 & 6.82 & 3.33 & 0.00 & 3.67 & 5.25 & 0.96 & 0.02 \\
\hline & \multirow{3}{*}{ TR } & 2009 & 3.67 & 2.45 & 5.44 & 0.00 & 3.73 & 5.87 & 4.37 & 0.00 & 3.57 & 4.39 & 0.79 & 0.02 \\
\hline & & 2010 & 3.77 & 5.33 & 4.36 & 0.00 & 3.67 & 5.90 & 2.08 & 0.00 & 3.64 & 4.98 & 1.19 & 0.02 \\
\hline & & Mean & 3.72 & 3.88 & 4.91 & 0.00 & 3.70 & 5.89 & 3.23 & 0.00 & 3.61 & 4.68 & 0.99 & 0.02 \\
\hline \multicolumn{3}{|c|}{ Main-effect } & & & & & & & & & & & & \\
\hline \multicolumn{3}{|c|}{ Square } & 3.51 & $6.45 \mathrm{a}$ & $1.94 \mathrm{~b}$ & 0.02 & 3.75 & $5.44 b$ & $1.39 \mathrm{~b}$ & 0.05 & 3.75 & $4.80^{*}$ & $0.68 b^{*}$ & 0.03 \\
\hline \multicolumn{3}{|c|}{ Round } & 3.74 & $3.70 \mathrm{~b}$ & $5.44 \mathrm{a}$ & 0.00 & 3.70 & $6.35 \mathrm{a}^{*}$ & $3.28 \mathrm{a}^{*}$ & 0.00 & 3.64 & $4.97 *$ & $0.97 \mathrm{a}^{*}$ & 0.02 \\
\hline \multicolumn{15}{|c|}{ Sub-effect } \\
\hline \multicolumn{3}{|c|}{ NTR } & 3.61 & 5.34 & 3.78 & 0.01 & 3.74 & 6.17 & $2.44^{*}$ & 0.05 & 3.76 & 5.14 & $0.83 * \neq$ & 0.03 \\
\hline \multicolumn{3}{|c|}{ TR } & 3.65 & 4.81 & 3.61 & 0.02 & 3.71 & 5.63 & $2.23 *$ & 0.00 & 3.64 & 4.63 & $0.83 * \neq$ & 0.02 \\
\hline
\end{tabular}

${ }^{1)}$ SMM: Silage making method, ${ }^{2}$ Square: Square bale, ${ }^{3)}$ Round: Round bale, ${ }^{4)}$ NTR: Non-treatment, ${ }^{5)}$ TR: Treatment $\mathrm{a}$ and $\mathrm{b}$ : Means with different letters within a column are significantly different at the $5 \%$ level.

* vs Milk stage $(\mathrm{P}<0.05)$, $\ddagger$ vs Yellow ripen stage $(\mathrm{P}<0.05)$.

수확시기가 늦어짐에 따라 높게 나타났으며 젖 산균 첨가에 의해서도 무첨가 보다 Flieg's score는 경미하게 상승하는 것으로 나타났다. 유숙기 옥수수 사각 압축곤포 사일리지의 Flieg's score (92점, 우수)는 원형곤포 사일리지 (62점, 양호) 보다 증가하였으나 황숙기와 완숙기에는 비슷한 경향을 나타냈다.

이상의 유기산 함량 및 Flieg's score의 결과 에서 보는 바와 같이 유숙기와 같이 수분 함량 이 높은 상태에서 옥수수 사각 압축곤포 사일 리지 조제는 원형곤포 사일리지 보다 젖산 함 량이 증가되고 초산함량이 감소하여 원형곤포 사일리지 보다 사일리지 품질이 현저하게 향상
되기 때문에 수분함량이 많은 상태에서도 옥수 수 사각 압축곤포 사일리지 조제방법은 양질의 옥수수 사일리지를 조제하는데 적합한 방법 (우 수)으로 사료된다. 특히, 수분함량이 많은 상태 에서 원형곤포 사일리지를 제조하는 것은 사일 리지의 품질(양호)을 저하시키는 원인이 되기 때문에 원형곤포 사일리지를 제조할 경우에는 수분함량이 적은 황숙기 (우수)에 사일리지를 조제하는 것이 좋을 것으로 생각된다. 특히, 사 각 압축곤포 사일리지는 유숙기와 같이 수분함 량이 많은 조건에서도 양질의 사일리지를 만들 수 있는 장점이 있기 때문에 소규모 양축농가 나 영세 양축농가에서는 좋은 사일지지 제조 


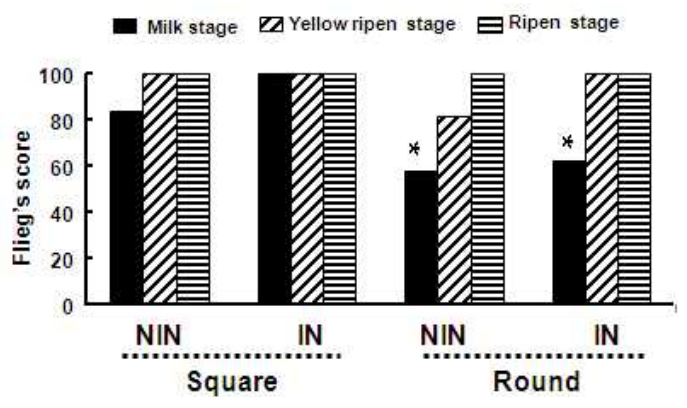

Fig. 3. Change of Flieg's score of square baled corn silage according to harvest time of corn and inoculant treatment.

NIN: Non-inoculation of inoculant, IN: Inoculation of inoculant, Square: Square bale, Round: Round bale.

* vs Milk stage $(\mathrm{P}<0.05)$.

방법이 될 수 있다고 생각한다.

신과 윤 (1983)은 사초가 예건을 통하여 적정 수분 함량에 도달되면 homo fermentation이 유 도되어 젖산비율이 높아진다고 하였는데, 본 연구에서는 수분 함량의 과소에 상관없이 젖산 비율이 높아지는 것을 알 수 있었는데, 이는 Cai 등 (2005)이 보고한 것처럼 옥수수는 젖산 균의 영양원이 되는 가용성 탄수화물이 타 작 물에 비하여 월등히 많은 양을 가지고 있기 때 문인 것으로 생각된다.

이상의 결과를 종합해 보면 옥수수 사각 압 축곤포 사일리지의 제조는 황숙기가 적기로 판 단되지만 농가의 여건에 따라 황숙기 전후에도 양질의 사각 압축곤포 사일리지가 제조가 가능 하기 때문에 원형곤포 사일리지보다 많은 장점 이 있는 것으로 생각된다. 그리고 본 연구에서 는 사일리지의 물리화학적 특성이 제조방법별, 젖산균 유무 등에 따라 차이를 보이지 않고 있 는데, 이는 옥수수내 당분 함량이 충분하면서 실험 여건상 사일리지 제조시 최적의 상태를 유지하기 위해 사일리지 제조시 밀봉 및 보관 등을 잘 유지하였기 때문인 것으로 생각된다. 그러나 일반농가의 대부분은 농사 여건에 따라 사일리지를 제조하기 때문에 수확시기, 답압 및 밀봉 등에 주의를 기울이지 않은 경우가 많
으므로 사일리지의 품질에 영향을 줄 수 있는 많은 요인을 고려하여 사일리지를 제조해야 한 다. 그러므로 양질의 사각 압축곤포 사일리지 를 제조하고자 할 때에도 반드시 젖산균을 첨 가할 뿐 아니라 압축 사일리지가 들어있는 포 장지 상단부의 공기를 제거하고 난 다음 실링 기로 완전 밀봉하여 혐기상태를 잘 유지함으로 써 사일리지의 품질을 향상시킬 수 있을 것으 로 기대된다. 따라서 소형 사각 압축곤포 사일 리지의 품질이 일반 원형곤포 사일리지와 비교 하였을 때 품질 면에서는 차이가 없기 때문에 소형 사각 압축곤포 사일리지는 운반, 취급 및 유통이 편리하다는 많은 장점이 있어 사각 압 축곤포의 이용 가능성은 높다고 생각된다. 그 러므로 소형 사일리지 제조에 많은 관심을 갖 고 다양한 방향에서 더 많은 연구가 진행되어 야 할 것으로 생각된다.

\section{IV. 요 약}

본 시험은 수확시기가 옥수수 사각 압축곤포 사일리지의 품질에 미치는 영향을 구명하기 위 하여 2009년부터 2010년까지 국립축산과학원에 서 수행되었다. 옥수수 사일리지 전용 품종인 광평옥을 이용하여 숙기별 3 회 (유숙기, 황숙기 및 완숙기)에 걸쳐 수확을 하여 사일리지로 조 제하였다. 숙기가 진행됨에 따라 옥수수 원형 곤포 사일리지의 조단백질 함량은 감소하는 경 향을 보였으나 $(\mathrm{P}<0.05) \mathrm{ADF}$ 및 $\mathrm{NDF}$ 함량은 차이가 나타나지 않았다. 그리고 $\mathrm{TDN}$ 및 in vitro 건물소화율도 비슷하였다. 숙기별 수분함 량, $\mathrm{pH}$ 및 사료가치는 사일리지 제조 방법 및 젖산균에 의해 영향을 받지 않았다. 유숙기에 서 옥수수 사각 압축곤포 사일리지의 젖산 함 량은 원형곤포 사일리지보다 현저하게 증가하 였으나 $(\mathrm{P}<0.05)$ 황숙기에서는 현저하게 감소하 였다 $(\mathrm{P}<0.05)$. 숙기별 사각 압축곤포 사일리지 의 초산 함량은 원형곤포 사일리지보다 현저하 게 감소하였다 $(\mathrm{P}<0.05)$. 유숙기에서 옥수수 사 
각 압축곤포 사일리지의 Flieg's score는 원형곤 포 사일리지보다 약간 증가하였으나 황숙기와 완숙기에는 비슷한 경향을 나타냈다. 그리고 옥수수 사각 압축곤포 사일리지와 원형곤포 사 일리지의 Flieg's score는 젖산균에 의해서 영향 을 받지 않았다. 따라서 본 연구에서는 옥수수 사각 압축곤포 사일리지는 새로운 사일리지 제 조방법이 될 수 있고 또한 양질의 옥수수 사일 리지 발효에 적합한 것으로 나타났다.

\section{$\mathrm{V}$. 인 용 문 헌}

1. 김정갑, 한민수, 김건엽, 한정대, 강우성, 신정남. 1995. 주요 사료작물의 곤포 Silage 조제이용에 관한 연구. II. 생육단계별 건물 축적 형태와 곤 포사일리지 조제이용. 한초지 15(3):157-230.

2. 김종덕, 권찬호, 김종근, 김창현, 노환국, 윤영만, 이종경. 2009. 조사료 생산 및 이용. 신광종합출 판사.

3. 김상록, 김곤식, 우제훈, 이준우, 성경일. 2004. 연천지역에 있어서 생볏짚 원형곤포 사일리지의 부위별 사료성분 및 발효품질. 한초지 24(3): 253-260.

4. 김종근, 정의수, 서 성, 함준상, 윤세형, 임영철. 2006a. 유산균제 첨가가 라운드베일 목초 사일리 지의 품질에 미치는 영향. 한초지 26(3):139-146.

5. 김종근, 정의수, 서 성, 강우성, 함준상, 김동암. 2001. 수확시 숙기가 호밀 라운드베일 사일리지 의 품질변화에 미치는 영향. 한초지 21(1):1-6.

6. 김종근, 정의수, 서 성, 김맹중, 이종경, 윤세형, 임영철, 조용민. 2008. 수확시기 및 품종이 총체 벼 사일리지의 품질에 미치는 영향. 한초지 28 (1):29-34.

7. 김종근, 서성, 정의수, 강우성, 함준상, 김동암. 2000a. 수확시 숙기가 호밀 라운드베일 사일리지 의 사료가치 변화에 미치는 영향. 한초지 20 (4):215-316.

8. 김종근, 정의수, 서 성, 함준상, 김맹중, 이종경. 2006b. 예건기간이 라운드베일 목초 사일리지의 품질에 미치는 영향. 한초지 26(1):39-44.

9. 김종근, 정의수, 서 성, 강우성, 함준상, 이성철. 2000 c. 제조 방법이 라운드베일 연맥 사일리지의 품질에 미치는 영향. 한초지 20(3):185-192.

10. 김종근, 정의수, 서 성, 강우성, 함준상, 이성철. 2000b. 제조 방법이 라운드베일 연맥 사일리지의 품질에 미치는 영향. 한초지 20(3):147-232.

11. 김종덕, 이현진, 전경협, 양가영, 권찬호, 성하균, 황보순, 조익환. 2010. 수확시기, 예건 및 싸라기 처리가 유기 청보리의 사초 생산성 및 사일리지 품질에 미치는 영향. 초지조사료지 30(1):25-34.

12. 김정갑, 진현주, 신재순, 정의수, 한민수. 1996. 봄 재배 연맥의 silage 제조 이용시 예건 및 formic acid 처리에 의한 품질개선 효과. 한초지 16(2):155-160.

13. 농림수산식품부. 2010. 2010년 조사료대책 추진 관련 협의회 p. 24.

14. 농촌진흥청. 2009. 유통사일리지 품질기준 현장 적용 세미나. 농촌진흥청 국립축산과학원.

15. 송태화, 한옥규, 윤성근, 박태일, 김경훈, 김기종. 2009. 청보리의 수확시기별 예건시간에 따른 수 분과 사일리지 품질변화. 한농개발지 21(4):316321.

16. 신기남, 윤익석. 1983. 예건이 silage의 품질에 미 치는 영향. 한초지 3(2):92-99.

17. 신재순, 최종만, 김은모, 김원호, 정민웅. 2009. 사각압축 사일리지 조제장치. 한국특허정보원, IPC 코드 A23N 17/00(2006.01), 출원번호 1020090003621 (2009.01.16), 공개번호 1020100084246 (2010.07.26)

18. 임현진, 김종덕, 이현진, 전경협, 양가영, 권찬호, 윤세형. 2009. 예건이 수수 $\times$ 수단그라스 교잡종 유기 사일리지의 품질에 미치는 영향. 한유농지 17(4):519-527.

19. AOAC. 1990. Official method of analysis. 15th ed. Washington, DC.

20. Bevre, L. 1988. Silage making in round bales. Buscap Og Avdratt. 40(2):100-103.

21. Cai, Y. 2005. Quality improving technique of whole crop silage. 축산연구소. 사료용 총체 벼 생산 - 이용 기술 국제 심포지엄 proceedings. pp. 103-136.

22. Jurgens, M.H. 1982. Animal feeding and nutrition. Kentall \& Hunt Publishing, Inc. Virginia.

23. Goering, H.K. and P.J. Van Soest. 1970. Forage fiber analysis. Agic. Handbook 379, U. S. Gov. Print. Office, Washington, DC.

24. Gordon, F.J. 1989. An evaluation through lactating cattle of a bacterial inoculant as an additive for grass silage. Grass Forage Sci. 44:169-179.

25. Hristove, A.N. and T.A. McAllister. 2002. Effect 
of inoculants on whole-crop barley silage fermentation and dry matter disappearance in situ. J. Anim. Sci. 80:510-516.

26. Keady, T.W.J. and J.J. Murphy. 1996. Effects of inoculant treatment on ryegrass silage fermentation, digestibility, rumen fermentation, intake and performance of lactating dairy cattle. Grass and Forage Sci. 51:232-241.

27. Keady, T.W.J. and R.W.J. Steen. 1994. Effects of treating low dry matter grass with a bacterial inoculant on the intake and performance of beef cattle and studies on its mode of action. Grass and Forage Sci. 49:438-446.

28. Kennedy, S.J., H.I. Gracey, E.F. Unsworth, R.W.J. Steen and R. Anderson. 1989. Evaluation studies in the development of a commercial bacterial inoculant as an additive for grass silage. 2 . Responses in finishing cattle. Grass and Forage Sci. 44:371-380.

29. Manyawa, G.J., S. Sobanda, C. Mutisi, I.C. Chakoma and P.N. Ndiweni. 2003. Effect of prewilting and incorporation of maize meal on the fermentation of bana grass silage. Asian-Aust. J. Anim. Sci. 16(6):843-851.

30. Moore, J.E. 1970. Procedure for the two-stage in vitro digestion of forage. Univ. of Florida, Depart. of Anim. Sci.
31. Patterson, D.C., C.S. Mayne, F.J. Gordon and D.J. Kilpatrick. 1997. An evaluation of an inoculant/ enzyme preparation as an additive for grass silage for dairy cattle. Grass and Forage Sci. 52:325335.

32. Romahn. W. 1988. Big bale haylage fits our operation. Moard's Adiryman. March 10. Hoard and sons company. Fort Akinson, Wisconsin. p. 255.

33. Smith, E.J., A.R. Henderson, J.D. Oldham, D.A. Whitaker, K. Aitcheson, D. H. Anderson, and J. M. Kelly. 1993. The influence of an inoculant/ enzyme preparation as an additive for grass silage offered in combination with three levels of concentrate supplementation on performance of lactating dairy cows. Anim. Prod. 56:301-310.

34. Steen, R.E.J., E.F. Unsworth, H.I. Gracey, S.J. Kennedy, R. Anderson and D.J. Kilpatrick. 1989. Evaluation studies in the development of a commercial bacterial inoculant as an additive for grass silage. 3. Responses in growing cattle and interaction with protein supplementation. Grass and Forage Sci. 44:381-390.

(접수일: 2011년 2월 21일, 수정일 1차: 2011년 3월 1일, 수정일 2차: 2011년 3월 14일, 게재확정일: 2011년 3월 25일) 